\title{
Evidence for a sauropod-like metacarpal configuration in stegosaurian dinosaurs
}

Phil Senter

Acta Palaeontologica Polonica 55 (3), 2010: 427-432 doi: http://dx.doi.org/10.4202/app.2009.1105

The stegosaurian forelimb is usually portrayed with the metacarpals slanted and distally spread. However, manual manipulation of stegosaurian metacarpals reveals that in that configuration they do not articulate with each other nor with the rest of the forelimb. Rather, they do articulate with each other and with the rest of the forelimb when posed vertically and arranged in a compact, semi-tubular configuration, as in sauropods. This configuration agrees with data from articulated specimens and trackways. As with sauropods, this metacarpal configuration makes retention of phalanges awkward for locomotion and may be functionally related to the vestigiality of the manual phalanges of the outer digits.

Key words: Dinosauria, Ornithischia, Stegosauria, forelimb, functional morphology.

Phil Senter [psenter@uncfsu.edu], Department of Natural Sciences, Fayetteville State University, 1200 Murchison Road, Fayetteville, North Carolina 28301, United States.

This is an open-access article distributed under the terms of the Creative Commons Attribution License (for details please see creativecommons.org), which permits unrestricted use, distribution, and reproduction in any medium, provided the original author and source are credited. 